ORIGINAL RESEARCHARTICLES

\title{
"You Cannot Hide Forever Luke": Understanding the Strategic Use of Sustainability Disclosure in the Short and Long Term
}

\author{
Samuel Touboul' and Asli Kozan²* \\ 'Society and Organizations Research Center, HEC Paris, France; '2Department of Strategy and Management, IPAG \\ Business School, Paris, France
}

\begin{abstract}
This study investigates the relationships among firms' sustainability disclosure, sustainability performance, and financial performance. Based on legitimacy theory and signaling theory, it argues that sustainability disclosure participates in two distinct mechanisms: a conformity mechanism through which disclosure shows conformity to the norms and a revelation mechanism through which disclosure reveals or hides a firm's achieved degree of sustainability. In an attempt to contrast and reconcile the two mechanisms, the study assesses their impact on financial performance in the short and long term. Hypotheses are tested using longitudinal data (2002-20 I0), which cover I0,8 4 observations of firms from major indexes of stock exchanges worldwide. The results show that the conformity mechanism is effective in both the short and long terms, whereas the revelation mechanism is only effective in the short term. As a consequence, firms with poor sustainability performance may hide their detrimental impact and achieve higher financial performance in the short term by limiting their disclosure but not in the long term in which their lack of conformity is punished. In the long term, only conformity to the norms of disclosure leads to higher financial performance, even in the case of poor sustainability results.
\end{abstract}

Keywords: Sustainability disclosure; Sustainability performance; Financial performance; Conformity mechanism; Revelation mechanism

Received: 7 November 20 I8; Accepted: 17 December 20 19; Published: 30 March 2020

1 2015, when the German car manufacturer Volkswagen (VW) was determined to have installed software designed to cheat nitrogen oxide emission tests in its diesel cars and, moreover, for incorrectly reporting its carbon dioxide $\left(\mathrm{CO}_{2}\right)$ emissions, the company found itself facing a sharp fall in stock price, multiple investigations, and heavy fines amounting to millions of dollars (McGee, 20 I7). Similarly, British Petroleum (BP) had long been praised for its investments in solar energy and was rated as one of the greenest oil companies (Röhrbein, 20 I0). However, when its Deepwater Horizon oil rig collapsed in 2010, BP lost all public support, which dramatically threatened its financial performance (Vaughan, 20 I 8). What WW and BP had in common is that, for years, they had been able to mislead their stakeholders about the true nature of their environmental performance. They had adjusted the information provided to stakeholders, i.e. the disclosure of their environmental performance and had thereby reached above-average returns. Those returns suddenly dropped the day each of those two firms' misbehaviors were revealed.
Concerned by the future of our planet, as well as social problems such as income inequalities and quality of life, stakeholders are putting increasing pressure on businesses to address current social and environmental issues (Albertini, 20I4; Baldini, Maso, Liberatore, Mazzi, \& Terzani, 20 I8). Addressing multiple and sometimes conflicting stakeholder demands is not an easy task and might create organizational hypocrisy (Cho, Laine, Roberts, \& Rodrigue, 2015) in firms' actions. However, businesses cannot remain unreceptive to these pressures; hence, companies engage in social and environmental initiatives at an increasing rate, while at the same time trying to meet their profit maximization goals. For the purposes of this study, we label firm initiatives that address social and environmental concerns as sustainability-related actions and the impact of a firm's actions in these areas, i.e. the performance of the firm as sustainability performance. There is a need to clearly differentiate the responsibility, actions, and performance of firms in terms of social and environmental issues. Aguinis and Glavas (2012, p. 933) define corporate social responsibility as

*Corresponding author: Asli Kozan, E-mail: asli.kozan@ipag.fr 
"context-specific organizational actions and policies that take into account stakeholders' expectations and the triple bottom line of economic, social, and environmental performance". The effectiveness of those actions and policies in addressing social and environmental issues corresponds to firms' social and environmental performance or, as increasingly used in the international scene, such as by the United Nations, European Union, and Global Reporting Initiative (GRI), firms' sustainability performance. Consequently, we define sustainability disclosure as the amount of information transmitted by a firm about its sustainability performance to its stakeholders.

The starting point of this study is that firms strategically use their sustainability disclosure to impact stakeholders' perceptions of the firm, thus ensuring stakeholder support. There is a stream of literature that remains skeptical about sustainability disclosure, considering it just a fad (Gray, 1992; Gray \& Milne, 2002). However, we follow the opposite perspective that disclosure might help in decision-making for managers and stakeholders alike by providing useful information on the sustainability performance of firms (Burritt \& Schaltegger, 20 I0; Schaltegger \& Wagner, 2006). The WW and BP stories provide anecdotal evidence that firms might engage in selective or even manipulative sustainability disclosure (Marquis, Toffel, \&Yanhua, 20 I6) to impact stakeholders' judgment of a firm. However, the amount of information to be transmitted to stakeholders, i.e. the extent of an 'optimum' sustainability disclosure is a difficult task for firms, especially if they have low sustainability performance. Therefore, there is a baseline question: Do less sustainable firms reach higher financial performance via hiding their poor sustainability performance results or are they better off conforming to the norms of disclosure?

This study investigates the links among sustainability disclosure, sustainability performance, and firm financial performance. It argues that disclosure engages in two mechanisms in line with the predictions of two theories but with paradoxical effects on financial performance: the conformity mechanism and revelation mechanism. Legitimacy theory, on the one hand, posits that sustainability disclosure itself relates to a firm's conformity to stakeholders' expectations and is used as a legitimizing tool by the firm (Deegan, 2002; Mahadeo, Oogarah-Hanuman, \& Soobaroyen, 201 I; Philippe \& Durand, 201 I; Reid \& Toffel, 2009). Hence, as the extent of the sustainability disclosure increases, it elicits higher stakeholder support and legitimacy, which eventually transforms into higher financial performance (Wang \& Qian, 20 I I). Signaling theory, on the other hand, argues that disclosure plays an indirect role in eliciting stakeholder support by revealing the true nature of a firm's sustainability performance. Firms have an interest in extensive disclosure if they want to reap the benefits of their social and environmental success (Hawn \& loannou, 2016); however, if the firm has low sustainability performance, it might be better off giving noisy signals to stakeholders (Hummel \& Schlick, 2016) and leaving them in doubt by limiting their disclosure (Mahoney, Thorne, Cecil, \& LaGore, 2013). In short, extensive disclosure is valued by stakeholders as a sign of conformity to the norms (conformity mechanism) but risks revealing information about poor sustainability results (revelation mechanism). Therefore, sustainability disclosure is a double-edged sword that may both benefit and penalize financial performance (Cormier \& Magnan, 1999; Zhang \& Wang, 2009). Thus, we look at the role that sustainability disclosure plays in the financial performance of a firm, as well as try to determine which mechanism, conformity or revelation, is most effective in the relationship between the two.

This study argues that the two mechanisms of conformity and revelation are not contradictory but do not operate in the same way and are not effective in the same time horizon. It shows that the conformity mechanism has both a short- and long-term impact on financial performance via imminent stakeholder support, legitimacy, and trust obtained, whereas the revelation mechanism only has a short-term impact on financial performance because stakeholders are eventually able to make an objective assessment of the firm either as a result of repeated interactions or from receiving involuntary signals about the sustainability performance of firms with limited sustainability disclosure. The proposed hypotheses are empirically tested using longitudinal data (2002-2010) with a sample of 2,522 firms (10,814 observations) from across 58 different countries and are supported.

The study aims to contrast and reconcile the two theoretical perspectives - legitimacy theory and signaling theory on sustainability disclosure. It addresses scholarly work that investigates disclosure as a normative process and underlines the existence of pressure for conformity to the norms of disclosure (Mahadeo et al., 20l I; Philippe \& Durand, 20l I; Reid \& Toffel, 2009), as well as studies that consider disclosure in light of the revelation mechanism as a way for a firm to reveal or hide some underlying characteristics of interest (King, Lenox, \& Terlaak, 2005; Mahoney et al., 20 I 3). By showing that both mechanisms exist and, thus, sustainability disclosure has both a direct impact on financial performance and a moderating impact on the relationship between sustainability performance and financial performance but on different time horizons, the study aims to advance the emerging stream of literature that contrasts these two theoretical perspectives to understand the relationship between sustainability disclosure and sustainability performance (Cho et al., 2015; Hummel \& Schlick, 20 I6; Mahoney et al., 20।3), as well as the literature investigating the relationship between sustainability performance and financial performance and its boundary conditions (Eccles, loannou, \& Serafeim, 2014; Rodriguez, Cotran, \& Stewart, 2017). 


\section{Theoretical framework}

\section{Stakeholders and sustainability performance}

A firm operates in an environment consisting of organizations and individuals that have stakes in the firm's realization of its objectives, namely, its stakeholders. Stakeholders are defined broadly as "any identifiable group who can affect the achievement of an organization's objectives, or who are affected by the achievement of an organization's objectives" (Freeman \& Reed, 1983, p. 91). We thus assume that firms in the pursuit of their objectives seek certain stakeholders' support.

A firm's sustainability actions embrace social and environmental concerns and demonstrate active engagement vis-à-vis stakeholders (Jones, 1995), even though meeting all the demands of numerous stakeholders that influence firm activities is not possible (Dessain, Meier, \& Salas, 2008). Firms adopt new policies and engage in sustainability actions to take into account stakeholders' expectations; however, whether these policies and actions are actually effective and efficient in bringing about changes remains questionable. If a firm's sustainability actions are indeed effective in bringing about a change, it may lead to positive sustainability performance, which by aligning the firm and its stakeholders' interests triggers stakeholder support. For instance, if a firm provides its employees with advantageous working conditions, those employees may accept lower-paid contracts and will not hesitate to work extra hours (Cespa \& Cestone, 2007; Turban \& Greening, 1997). If a firm performs well in protecting the environment, it may mitigate government pressure and attract more customers (Hillman \& Keim, 200I). Sustainability performance ensures good stakeholder relations, and pleased stakeholders will be more likely to return the 'favor' to the firm by reducing its costs and increasing its revenues in both the short and long terms (Choi \& Wang, 2009; Eccles et al., 2014) and help the firm eventually achieve better financial performance (Waddock \& Graves, 1997).

However, regardless of whether it is environmental or social, sustainability performance is by its nature not an easily observable characteristic of firms (King \& Toffel, 2009; King et al., 2005; Jiang \& Bansal, 2003). As King and Toffel (2009, p. 104) state, "Customers cannot determine by inspection whether or not the cotton in a pair of trousers was grown in an organic manner, or a pound of coffee beans was grown under a natural forest canopy". To assess a firm's sustainability performance, stakeholders first look into the disclosure of the firm on its sustainability performance.

\section{Sustainability disclosure}

As previously mentioned, sustainability disclosure is the amount of information firms transmit to stakeholders on their sustainability performance. Disclosure is not of a dichotomous nature: firms do not either disclose or not, and they are not either silent or fully transparent. Aware of this, scholars often use an index to evaluate the extent of firm disclosure (see, e.g., Cho, Guidry, Hageman, \& Patten, 2012; Clarkson, Li, Richardson, \& Vasvari, 2008 for firm environmental disclosure). First, legislation in an increasing number of countries prevents firms from being completely silent and requires a minimum of reporting, such as in the European Union, which introduced Directive 2014/95/EU on mandatory sustainability reporting in October 2014 (Hummel \& Schlick, 2016). Second, due to the cost of disclosure, firms' geographical scope of activities and organizational complexity, and conflicting stakeholder demands, full disclosure can almost never be reached (Cho et al., 2015; Criado-Jiménez, FernándezChulián, Larrinage-González, \& Husillos-Carqués, 2008).

Therefore, firms strategically modulate the information they make available to stakeholders about their environmental or social impact (Cho, Roberts, \& Patten, 20I0) and either reveal an extensive number of indicators on their sustainability performance or limit the disclosure of those indicators. For instance, firms may communicate about some philanthropic activities but omit polluting emissions, and they can adopt only one or several green standards. Information may be hidden in annual reports or published as stand-alone reports. In other words, firms may disclose a varying amount of indicators of their sustainability performance and adopt more or less stringent certifications (Mahadeo et al., 20II; Roulet \& Touboul, 2015). Briefly, firms adjust their sustainability disclosure and, hence, the amount of information available to stakeholders (Ullmann, 1985). For the purposes of this study, we distinguish between two levels of sustainability disclosure - extensive and limited - based on the amount of information that a firm reveals to stakeholders regarding its sustainability performance. A focal firm may either adopt an extensive disclosure, in which it discloses a large amount of information and a high number of indicators about its sustainability performance, covering all aspects of the firm's social and environmental impacts, or opt for a limited disclosure, in which it discloses a small amount of information that, for instance, limits available figures on its social performance or does not communicate regarding green certifications.

Based on this information, two questions arise: how do stakeholders interpret extensive and limited sustainability disclosure? Does a firm achieve better financial performance via extensive or limited sustainability disclosure? As previously mentioned, this study argues that sustainability disclosure participates in two mechanisms - conformity and revelation which have contradicting effects on firm financial performance. These mechanisms are investigated in the next sections.

\section{Legitimacy theory, sustainability disclosure, and conformity mechanism}

Normative pressures from civil society, non-governmental organizations (NGOs), media, and even shareholders for social and 
environmental impact disclosure have risen over recent years (Albertini, 2014; Baldini et al., 2018; Flammer, 2013) along with the emergence and strengthening of stakeholder orientation in the markets (loannou \& Serafeim, 20I5). Disclosing extensively on firm environmental or social performance and, thus, disclosing on sustainability performance is considered appropriate by stakeholders (Huang \& Kung, 201 0; Michelon, 201 I; Philippe \& Durand, $20 \mathrm{l}$ I). Via disclosure of its sustainability performance, a firm conforms to the normative institutional pressures and underlines that its values are aligned with those of stakeholders, who, in return, attribute to the firm a higher legitimacy (Deephouse, 1996; Suchman, 1995). In other words, disclosure in itself relates to firms' conformity to stakeholders' expectations and is used as a legitimizing tool by firms (Cho \& Patten, 2007; Mahadeo et al., 20 I I; Philippe \& Durand, 20 I I; Reid \& Toffel, 2009). Higher legitimacy elicits stakeholder support, which eventually may transform into higher financial performance (Wang \& Qian, 20 I I) and lower total and idiosyncratic risks for the firm (Benlemlih, Shaukat, Qiu, \& Trojanowski, 20 I 8). In this perspective, firms with extensive sustainability disclosure achieve higher financial performance than those with limited disclosure. Hence, the strategic value of sustainability disclosure relies on whether it participates in a conformity mechanism, which implies that stakeholders not only support sustainable firms but also those that conform to the norms of disclosure. Consequently, even when the sustainability performance of the firm is weak, the firm has an interest in extensive disclosure because it is appreciated by stakeholders. For instance, for environmental performance, legitimacy theory predicts that poor environmental performers under social pressure are expected to have a higher level of environmental disclosure to change stakeholders' perceptions about their actual performance (Clarkson et al., 2008). Indeed, firms in more sensitive industries, such as construction and energy, tend to disclose more on their environmental performance than those in industries that are less scrutinized, such as optical or biological sectors (Albertini, 20 14; Cho \& Patten, 2007), and worse environmental performers disclose more (Cho \& Patten, 2007; Patten, 2002). The conformity mechanism also implies that firms limiting their disclosure lose legitimacy and suffer from negative consequences, such as the loss of stakeholder support (Hahn \& Lülfs, 20 I 4), and that, therefore, all firms have an incentive for extensive disclosure, even if it is to reveal a detrimental impact of the firm on society or the environment. This way, the firm shows stakeholders that even if a beneficial impact on society is not achieved, the company is aware of it and does not try to hide it with diversion tactics, such as greenwashing (Toffel \& Short, 2009).

\section{Signaling theory, sustainability disclosure, and revelation mechanism}

An alternative perspective on sustainability disclosure considers it a means to reduce the problem of asymmetric information between the firm and its stakeholders. This involves the firm the better-informed party - sending a signal that conveys relevant information to stakeholders - the less-informed party - to reduce the asymmetry (Connelly, Certo, Ireland, \& Reutzel, 201 I; Ragozzino \& Reuer, 201 I; Spence, 1973).

Although stakeholders seek information on a firm's sustainability performance, it is a latent construct that cannot be directly observed by stakeholders (Hawn \& loannou, 2016; King \& Toffel, 2009; King et al., 2005; Jiang \& Bansal, 2003). Stakeholders thus must rely on available but imperfect signals to decide whether to support a focal firm. Sustainability disclosure is one of those signals (King et al., 2005; Mahoney et al., 2013). By inspecting a firm's green certifications, sustainability reports, and communication supports, stakeholders are able to approximate a firm's degree of sustainability performance (Akerlof, 1970; Spence, 1973). Sustainability disclosure, therefore, appears to be a key strategic tool that participates in the revelation mechanism.

The revelation mechanism refers to whether sustainability disclosure signals reveal or hide from the stakeholders a firm's actual sustainability performance, and whether the firm meets stakeholder expectations in terms of such factors as environmental protection and social welfare (Clarkson et al., 2008; Ingram, 1978; Mahoney et al., 2013). However, signals can be more or less convincing (Greve, 20 I I), and a firm, in adjusting its sustainability disclosure, adjusts the amount of information contained in its sustainability signals. The more extensive the disclosure provided by the firm is, the more likely the signal will assure stakeholders of the reliability of a nonobservable or not easily observable characteristic of the firm - its sustainability performance. Firms only realize the full benefits of their social and environmental efforts when these are externally communicated to key stakeholders (Hawn \& loannou, 2016) and when firms provide detailed reports and hard indicators of their good environmental performance (Plumlee, Brown, Hayes, \& Marshall, 20I5). After receiving signals such as announcements of environmental or social engagements by the firm, stakeholders re-evaluate companies (Wassmer, Cueto, \& Switzer, 20l4).

In brief, the revelation mechanism implies two things: first, firms with high sustainability performance decrease the information asymmetry between the firm and external evaluators via extensive disclosure and, by revealing their beneficial impact on the environment and society, can reap the benefits of their sustainability performance (Hawn \& loannou, 2016; Plumlee et al., 20 I5). Second, when a firm limits its sustainability disclosure, this leads to doubt in stakeholders' assessments about the firm's actual degree of sustainability performance (Akerlof, 1970; Milgrom \& Roberts, 1986; Spence, 1973). Indeed, firms with low sustainability performance are found to provide low-quality information and to give noisy signals to stakeholders (Hummel \& Schlick, 2016). Firms with poor sustainability results might choose to leave stakeholders in doubt 
by limiting their disclosure on their detrimental sustainability impact (Mahoney et al., 2013) and may avoid losses by hiding their poor sustainability results, like BP and WW, for a limited period of time.

The revelation mechanism underlines the well-known paradox of disclosure: depending on the characteristic that is disclosed, disclosure can have opposite effects (Clarkson \& Toh, 2010 ; Milgrom \& Roberts, 1982). Extensive disclosure revealing high sustainability performance triggers stakeholders' support (Hawn \& loannou, 20 I 6), whereas extensive disclosure revealing detrimental behaviors triggers their defiance (Våland \& Heide, 2005) and might bring negative consequences for the firm.

\section{Contrasting legitimacy theory and signaling theory perspectives on sustainability disclosure}

The two mechanisms of conformity and revelation derive from two separate theoretical perspectives, i.e. legitimacy theory and signaling theory, consider the role of sustainability disclosure in eliciting stakeholder support differently, i.e. direct vs. moderating role, and predict opposing reactions from stakeholders and, thus, different consequences for the firm in terms of financial performance. Extensive disclosure enhances firms' financial performance by demonstrating conformity to the norms of disclosure (conformity mechanism) but penalizes less sustainable firms by revealing their detrimental impact on society (revelation mechanism). Conversely, limited disclosure protects the financial returns of a less sustainable firm by leaving its stakeholders uncertain of its poor sustainability performance results (revelation mechanism). However, by limiting its disclosure, such a firm may penalize its financial performance by not showing conformity to the disclosure norms (conformity mechanism).

It is, therefore, crucial to understand the relative effectiveness of both mechanisms. We argue that these mechanisms can be reconciled as long as the boundary condition is defined. To disentangle the impact of both mechanisms, we believe that there is a need to distinguish between their short- and longterm effects. We consequently develop hypotheses that assess the existence of the conformity and revelation mechanisms over the short and long term and their consequences in the relationships among sustainability disclosure, sustainability performance, and financial performance.

\section{Hypotheses}

\section{Conformity mechanism:The impact of sustainability disclosure on financial performance in the short and long term}

Increasing attention from the public on social and environmental issues in the past few decades (Albertini, 20 I4; Flammer, 20 I3) have put firms under the spotlight regarding their sustainability performance. Facing the pressure, firms disclose their sustainability performance either extensively or in a limited way, as previously mentioned. Information on firms' sustainability performance is widely spread, quickly available and disseminated, and scrutinized by stakeholders (Marquis et al., 2016). Guidry and Patten (2010) found, for instance, that the more firms conform to disclosure standards suggested by the GRI, the more they experience a positive market reaction following the release of their sustainability reports. Similarly, abnormal stock market returns have been observed following firm disclosure of sustainability initiatives targeting a positive impact on the environment (Wassmer et al., 2014).

Stock market reactions to sustainability disclosure indicate that stakeholders are capable of assessing in a short period of time whether a firm conforms to their disclosure expectations. Stakeholder support follows when firms conform to the norms via extensive disclosure. Therefore, by showing conformity to stakeholders' expectations, firms with extensive sustainability disclosure reach higher financial performance than firms with limited sustainability disclosure. Thus, we can propose the following hypothesis:

Hypothesis 1: Sustainability disclosure has a positive impact on firms' short-term financial performance.

If the conformity mechanism has a positive impact in the short term, what about the impact in the long term? Whether advantages such as superior financial performance derived from good stakeholder relations persist in the long run has been a question investigated in the literature (Choi \& Wang, 2009). We hypothesize that the conformity mechanism is effective in the long run for two reasons. First, extensive disclosure confirms to stakeholders that a firm possesses the attributes they desire (Ginzel, Kramer, \& Sutton, 1992; Suchman, 1995), and this social conformity leads to higher legitimacy (Cho \& Patten, 2007; Mahadeo et al., 20 I I; Philippe \& Durand, 201 I; Reid \& Toffel, 2009). However, legitimization is a cognitive and thus long-term process (Albertini, 20 I 4; Navis \& Glynn, 2010). There is a time lapse before this extensive disclosure transforms into legitimacy (Vaccaro, 20I2) and, in turn, to higher financial performance (Wang \& Qian, 201 I). Second, in the field of sustainability, firms are known to use symbols and impression management tactics to improve their legitimacy without effectively conforming to the norm (Cho, Laine, Roberts, \& Rodrigue, 2018; Cho et al., 2010). In this case, firms are suspected of 'greenwashing' (Delmas \& Burbano, 20 I I; Hahn \& Lülfs, 20 I4; Kim \& Lyon, 20I 5; Lyon \& Kim, 2007). Consequently, there exists a trust issue between firms and their stakeholders (Stanaland, Lwin, \& Murphy, $2011)$. Trust in any stakeholder relationship is only built over the long term (Barney \& Hansen, 1994), but once it is built, it may help mitigate firms' operational risks (Benlemlih et al., 
2018). As stakeholders are aware and cautious about greenwashing, legitimacy is always at stake and slow to obtain and only given to firms once trust is built between the parties. It has been shown that in the long run, firms with extensive disclosure are cognitively assimilated by stakeholders as those that provide a sufficient quantity of high-quality information (Beretta \& Bozzolan, 2008), which helps the firms build trust and obtain legitimacy. Consequently, firms with extensive sustainability disclosure achieve higher long-term financial performance than those with limited sustainability disclosure, leading to hypothesis 2 .

Hypothesis 2: Sustainability disclosure has a positive impact on firms' long-term financial performance.

\section{Revelation mechanism:The impact of sustainability disclosure on the link between sustainability performance and financial performance in the short and long term}

The revelation mechanism assesses that a firm with extensive sustainability disclosure reveals its sustainability performance to its stakeholders, who adjust their support in return (Hawn \& loannou, 2016). In contrast, a firm with limited disclosure leaves its stakeholders in doubt about its social and environmental impact (Mahoney et al., 20 I3), and stakeholders are left uncertain about their decision to support the focal firm. Consequently, when the revelation mechanism is effective, the impact of sustainability performance on financial performance depends on the extent of the firm's sustainability disclosure, i.e. whether it is extensive or limited. According to this perspective, sustainability disclosure has an indirect effect on a firm's financial performance by moderating the relationship between its sustainability performance and financial performance. However, it is uncertain whether this mechanism functions in the same way in both the short and long terms.

Firms with extensive sustainability disclosure reassure stakeholders about their achieved degree of sustainability. For example, consumers looking at a firm's certifications, such as whether its coffee beans are grown in a sustainable way or the cotton used to make its clothing is organic, are able to form an evaluation of its sustainability performance (King \& Toffel, 2009). However, when a firm adopts a limited sustainability disclosure approach, its sustainability performance has a high probability of going unnoticed by stakeholders in the short term. A disclosure is only meaninguul to stakeholders if it reflects some credible underlying events (Jaggi \& Freedman, 1992), and limited disclosure does not allow stakeholders to assess the credibility of the sustainability performance that is presented. The noisier the signal, the less likely agents are to make a negative decision (Greve, 201 I). With limited information, in the best-case scenario, stakeholders cannot decide whether to support or penalize the focal firm. In the worstcase scenario, they base their decision on signals other than sustainability disclosure, such as the firm's reputation or legitimacy (Michelon, 20II). In both cases, sustainability performance remains unnoticed and, therefore, does not impact a firm's financial performance. Hence, in the short term, firms with extensive disclosure reap the benefits of their sustainability performance, whereas firms with limited disclosure do not.

Hypothesis 3a: Sustainability performance positively impacts the short-term financial performance of firms with extensive disclosure.

Hypothesis 3b: Sustainability performance has no impact on the shortterm financial performance of firms with limited disclosure.

We argue, however, that the revelation mechanism is only effective in the short term. In other words, in the long run, stakeholders can continue to clearly assess the sustainability performance of firms with extensive sustainability disclosure and are reassured of the firms' degree of engagement. For instance, a firm with extensive sustainability disclosure announcing better working conditions benefits in the long term from more motivated employees (Cespa \& Cestone, 2007) or from long-term contracts with the best suppliers. Consequently, firms with a positive sustainability performance and extensive disclosure are rewarded with higher long-term financial performance.

However, in contradiction with the short-term case, in the long term, stakeholders are more capable and likely to evaluate the sustainability performance of firms with limited disclosure for two reasons. First, limited disclosure leaves stakeholders in doubt about a firm's sustainability performance, so stakeholders are more likely to form their own related opinions over the long term. Also in the long term, the repeated interactions between a firm and its stakeholders and the cumulative disclosure of information, even if limited, decrease the asymmetry of information (Cui, Jo, \& $\mathrm{Na}, 2018$ ) and allow stakeholders to form a certain opinion about a firm's degree of sustainability performance. Second, even if in the short term stakeholders base their sustainability assessment on firms' voluntary sustainability disclosure, in the long term, there is a higher probability of involuntary disclosure. Involuntary disclosure refers to information about a firm's sustainability performance that is disclosed without control from the organization. This is the case, for instance, when environmental disasters are revealed by the media, as with $\mathrm{BP}$, or when information on disclosure fraud is revealed, as with WW. In the long term, due to the higher probability of NGO investigations and the leakage of information on negative incidents through third parties or whistleblowers, involuntary disclosure is more likely to occur and practices such as greenwashing are more likely to be revealed, which can create a backlash for the firm (Reimsbach \& Hahn, 20 I5; Våland \& Heide, 2005). 
Hence, in the long term, stakeholders are either able to make an assessment as a result of repeated interactions or have received involuntary signals about the sustainability performance of firms through limited sustainability disclosure. Therefore, in the long run, the revelation mechanism is not effective, as disclosure no longer plays a role in revealing or hiding a firm's degree of sustainability performance, i.e. disclosure ceases to moderate the relationship between sustainability performance and financial performance. Whatever the extent of a firm's sustainability disclosure - extensive or limited - sustainability performance has a positive impact on a firm's financial performance.

Hypothesis 4a: Sustainability performance positively impacts the longterm financial performance of firms with extensive disclosure.

Hypothesis 4b: Sustainability performance positively impacts the longterm financial performance of firms with limited disclosure.

\section{Data}

Regarding the data in this study, 9 years of sustainability disclosure and sustainability performance measures were extracted from the ASSET4 database (from 2002 to 2010). ASSET4 is a Swiss-based sustainability ratings agency and a subsidiary of Thomson Reuters that provides sustainability disclosure and sustainability performance ratings for 958 firms from 2002 and 3,258 firms from 2010. The data set covers major financial indexes worldwide and thus includes large companies from both developed ${ }^{2}$ and developing ${ }^{3}$ countries. It has been widely used in recent academic literature for its granularity and limited biases (Cheng, loannou, \& Serafeim, 2014; Eccles et al., 2014; Hawn \& loannou, 2016; Roulet \& Touboul, 2015). The 2002-2010 period is most relevant to test our hypotheses for two reasons. First, it covers periods of macro-economic growth, turmoil, and standstill, when firms may have had diverging incentives to invest in sustainability rather than other strategic opportunities. Second, 2002-2010 covers a period of transition when sustainability reporting became increasingly institutionalized:

\footnotetext{
1. These include the FTSE 250 (UK), S\&P 500, NASDAQ I00, Russell 1000 (US), S\&P Composite (Canada), SMI (Switzerland), DAX (Germany), CAC 40 (France), S\&P ASX 200 (Australia), DJ STOXX (Europe), and MSCl World (worldwide).

2. These include Australia, Austria, Bahamas, Belgium, Bermuda, British Virgin Islands, Canada, Cayman Islands, Cyprus, Czech Republic, Denmark, Finland, France, Germany, Gibraltar, Greece, Guernsey, Hong Kong, Hungary, Ireland, Isle of Man, Israel, Italy, Japan, Jersey, Republic of Korea, Luxembourg, Marshall Islands, Netherlands, New Zealand, Norway, Panama, Poland, Portugal, Spain, Sweden, Switzerland, United Kingdom, and the United States of America.

3. These include Brazil, Chile, China, Colombia, Egypt, India, Indonesia, Kuwait, Malaysia, Mauritius, Mexico, Morocco, Papua New Guinea, Philippines, Qatar, Russian Federation, Saudi Arabia, Singapore, South Africa, Taiwan, Thailand, Turkey, Ukraine, and the United Arab Emirates.
}

KPMG (201 I) states that in 201 I, 95\% of the 250 largest global companies published a sustainability report, whereas in 2002, only 45\% did so (Kolk, van der Veen, Hay, \& Wennink, 2002). Therefore, the institutionalization of sustainability disclosure that characterized this period is ideal to test our hypotheses, specifically the diverging effects of the conformity and revelation mechanisms.

Annually, ASSET4 analysts gather 1,359 indicators on firms' sustainability performance and disclosure through all publicly available sources (e.g. annual reports, Corporate Social Responsibility (CSR) reports, newspapers, and NGO websites). Raw data are then transformed through a proprietary algorithm into several ratings and sub-ratings. ASSET4 is one of the world's largest databases for extra-financial information. It is estimated that investors representing $€ 2.5$ trillion of assets use its data (Cheng et al., 20 I4). Although some scholars measure sustainability-related constructs using databases such as Kinder, Lydenberg and Domini (KLD) (Barnett \& Salomon, 2006; Surroca, Tribo, \& Waddock, 2010; Waddock \& Graves, 1997), Vigéo (Cavaco \& Crifo, 2014), Calvert, FTSE4Good, DJSI, or Innovest (Chatterji, Durand, Levine, \& Touboul, 20 I6), we prefer to rely on the ASSET4 database for its granularity, reliability, and higher adequacy within our theoretical setting. ASSET4 data are more granular than other rating agencies' data in the sense that it rates firms by scaled scores ( 0 to 100\%), whereas other agencies such as KLD only provide dichotomic indicators $(0$ or I). This granularity provides greater robustness to our econometric results. ASSET4 data are also less likely to be biased because its analysts do not use self-administered questionnaires as in other agencies, which limits the risk of misleading answers from rated firms. In addition,ASSET4 ratings are computed through algorithms applied to collected indicators. They are thus protected from cognitive biases that may arise from analysts' subjectivity. Finally, ASSET4 aptly fits our framework as it clearly differentiates between firms' sustainability performance (outcome of sustainability practices) and sustainability disclosure (amount of information provided). While most stakeholders do not observe a firm's actual sustainability performance, ASSET4 analysts collect and analyze hundreds of data sets and spend hours examining primary and secondary information. In comparison with stakeholders who have limited time and access to information, ASSET4 analysts are better positioned to evaluate the difference between what a firm actually did (its sustainability performance) and what it disclosed (its sustainability disclosure), which perfectly matches the purpose of this study.

We also gathered financial performance and control measures from Bureau van Dijk's ORBIS global database (audited financials of companies worldwide). Our final data set consists of the intersection between the ORBIS and ASSET4 databases for firms having available financial and sustainability data for at least three consecutive years. Our final sample is consisted of 
2,522 firms that belong to major indexes from the largest stock exchanges worldwide. These firms come from all industrial sectors ${ }^{4}$ and 58 different countries. Our final data set contains 10,814 observations between 2002 and 2010, with an average of 1,202 observations per year. Furthermore, each firm appears in the data set for an average of 6.3 years.

\section{Independent variables}

For each firm, ASSET4 provides 15 annual sustainability performance 5 ratings that cover 15 sustainability topics, including emission reduction, resource reduction, employment quality, and human rights. The 15 ratings are grouped into three general categories: environmental, social, and governance. ${ }^{6}$ Furthermore, the 15 sustainability performance ratings range from 0 to $100 \%$ and measure the impact of a firm's sustainability policies. Among the indicators used to compute the ratings are the amount of waste recycled, the amount of $\mathrm{CO}_{2}$ emissions, and the number of products targeting low-income consumers. The more a firm benefits its stakeholders, the higher its sustainability ratings (e.g. firms that recycle a large amount of waste obtain a higher 'resources reduction' rating, and firms with lower emissions of $\mathrm{CO}_{2}$ achieve a higher 'emission reduction' rating). To obtain our measure of sustainability performance, we computed the average of the 15 ASSET4 sustainability performance ratings with equal weights per general category, i.e. environmental, social, and governance. We thereby obtained from the 15 initial ASSET4 sustainability performance ratings a single sustainability performance measure. We averaged the 15 ratings with equal weights for each of the three general categories so that categories with a higher number of ratings did not overinfluence the final measure (e.g. the environmental category contained three ratings, whereas the social category contained seven ratings). Therefore, an increase in our measure of sustainability performance indicates that a firm increased its beneficial impact on stakeholders' welfare equally (e.g. lower pollutant emissions, fewer health and safety issues at work, or fairer governance), regardless of whether the firm improved its impact in terms of environmental, social, or governance performance.

\footnotetext{
4. These include energy, basic materials, industrials, cyclical consumer goods and services, noncyclical consumer goods and services, financials, healthcare, technology, telecommunications services, and utilities.

5. Labeled by ASSET4 as the 'performance' ratings within the broader category of the 'outcome' ratings.

6. The environment category includes three subratings: emission reduction, product innovation, and resource reduction. The social category includes seven subratings: product responsibility, community, human rights, diversity and opportunity, employment quality, health and safety, and training and development. The governance category includes five subratings: board functions, board structure, compensation policy, vision and strategy, and shareholder rights.
}

In the same way as the sustainability performance ratings, ASSET4 provides 15 sustainability disclosure ${ }^{7}$ ratings ranging from 0 to $100 \%$. These sustainability disclosure ratings cover the same 15 topics as the sustainability performance ratings and are also grouped into the same three general categories, i.e. environment, social, and governance. These 15 sustainability disclosure ratings measure the amount of information a firm publicly discloses about its sustainability performance for each of the 15 topics (e.g. Is information on $\mathrm{CO}_{2}$ emissions publicly available? Is information on employees' injuries at work publicly available)?. More precisely, ASSET4 analysts construct the sustainability disclosure measure by comparing the maximum number of indicators a firm could have disclosed (e.g. the amount of $\mathrm{CO}_{2}$ emissions or the number of injuries at work) with what it actually discloses. We computed our final measure of sustainability disclosure with the average of ASSET4's 15 sustainability disclosure ratings, equally weighted per general category, i.e. environmental, social, and governance. As a result, the value of our sustainability disclosure measure increases when firms disclose a greater number of indicators about their sustainability performance.

Because our hypotheses predict differing results for firms with extensive and limited disclosure in terms of financial performance, this necessitated a split in our sample between firms with limited disclosure and those with extensive disclosure. We thus computed a sustainability disclosure dummy that was coded I when firms performed at a level of sustainability disclosure superior to the rated median of all firms in the same year, and 0 otherwise. The baseline median was computed for every year, in which firms were split into equal size samples. We considered that firms coded with I implement extensive sustainability disclosure during a focal year, and those coded with 0 implement limited sustainability disclosure during the same year. By splitting firms between those with high and low sustainability disclosure using the median of all firms, rather than the median of firms from the same industry or country, we assume that stakeholders evaluate firms' absolute sustainability disclosure and not their sustainability disclosure relative to their industry or country peers. We draw this assumption from a large section in the literature that considers absolute measures of (environmental) disclosure (Cho et al., 2012, 2010) and evidence that NGOs tend to attack selected polluting industries (e.g. the energy sector and metals and mining industry) rather than the worst polluters in each industry (Reid \& Toffel, 2009). However, as a robustness test, we also estimated models taking into account differences between industries and countries in normative pressure (see the 'Robustness checks' subsection).

\footnotetext{
7. Labeled by ASSET4 as the 'transparency' ratings within the broader category of the 'outcome' ratings.
} 


\section{Dependent variable}

In line with the literature linking sustainability performance and financial performance, we measured financial performance with the firms' return on total assets (ROA) (Choi \& Wang, 2009; Hull \& Rothenberg, 2008; Waddock \& Graves, 1997). To measure the short-term financial performance, we considered firms' average ROA in the 2 years following the focal year when their sustainability performance and sustainability disclosure were measured. As an example, when the independent variable was a firm's sustainability disclosure in 2005, we considered its short-term financial performance as its average ROA during the 2006-2007 period; when the independent variable was a firm's 2006 sustainability disclosure, the dependent variable was its average ROA during the 2007-2008 period. In the same way, we measured firms' long-term financial performance by their average ROA over the 3rd and 4th years following the year when their sustainability performance and sustainability disclosure were measured. As an example, if the independent variable was a firm's 2005 sustainability disclosure, we considered its long-term financial performance as its average ROA during the 2008-2009 period. Measuring a firm's short-term financial performance by its forward-looking, 2-years' average ROA and its long-term financial performance by its average ROA in the 2 years following its short-term financial performance provides three things: first, consistency and comparability across our dependent variable measures (both 2 years' average); second, the ability to take advantage of the longitudinal dimension of our data (when independent variables are measured in year $n$, they are regressed on dependent variables measured in $n+1$ and $n+2$ or $n+3$ and $n+4)$; and, third and most importantly, the capability of limiting the risk of reverse causality. Although it may be argued that a firm's current financial performance (in year $n$ ) may influence its current sustainability performance or disclosure, the causality between a firm's future financial performance (in years $n+1, n+2, n+3$, and $n+4$ ) and current sustainability performance or disclosure (in year $n$ ) is much weaker.

\section{Control variables}

Following the literature on the links among sustainability performance, sustainability disclosure, and financial performance (Eccles et al., 2014; Hummel \& Schlick, 2016; Rodriguez et al., 2017), we controlled for the major determinants of firms' forward-looking, short- and long-term financial performance, such as their size, risk exposure, industrial sector, current financial performance, country of operation, and time effect.

We measured a firm's size with the logarithm of its total assets and its short-term risk exposure with the inverse of its liquidity ratio. ${ }^{8}$ The inverse liquidity ratio measures the risk that

8. (Current assets - stocks)/current liabilities. a firm may not be able to reimburse its debts in the short term. For models with long-term financial performance as a dependent variable, we also controlled for a firm's long-term risk exposure with the inverse of its solvency ratio. ${ }^{9}$ The inverse solvency ratio measures the risk that a firm may not be able to reimburse its debts in the long term.

To better cope with the risk of an endogeneity issue due to reverse causality, we also included as a control a firm's current financial performance as measured by its return on assets in the same focal year as its sustainability performance and sustainability disclosure were measured (the dependent variables of short- and long-term financial performance are measured in the 4 consecutive years). By doing so, we controlled for the cases in which more profitable firms had an incentive to invest in sustainability and disclose their efforts (reverse causality) to isolate the direct effect of sustainability performance and disclosure on financial performance.

We also controlled for the industry effect with a set of 25 dummies based on the first four digits of the firms'Thomson Reuters Business Classification codes and for the country effect with a set of 58 dummies based on the firms' country of incorporation. Our data being longitudinal (panel), we also controlled in all models for the time effect with year dummies. Descriptive statistics of our variables are presented in Tables I and 2.

Table I shows that firms endogenously select themselves and have a tendency to either adopt limited sustainability disclosure when their sustainability performance is low and extensive sustainability disclosure when their sustainability performance is high (0.84 correlation between the sustainability performance and sustainability disclosure variables). This supports our argument that firms play strategically with the revelation mechanism and tend to only reveal their sustainability performance when it is high. However, such a high correlation between the sustainability performance and sustainability disclosure constructs may create statistical endogeneity issues in models estimated with both measures as independent variables (multicollinearity between independent variables), which could have been a methodology to test hypotheses $3 a-4 b$. To cope with this endogenous multicollinearity issue, we first tried to include both sustainability disclosure and performance within the same estimated models using the classical technique of instrumental variables (e.g. using the rank or differential of sustainability disclosure or performance as instruments or using financial measures as instruments of either sustainability disclosure or performance). We also tried difference-in-differences models (impact of the year-on-year difference of sustainability disclosure and performance on the year-on-year difference of financial performance). However, the results, although

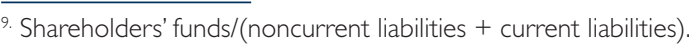


Table I. Listwise Pearson correlations of variables in models with short- or long-term financial performance as the dependent variable

Short-term financial performance as the dependent variable

\begin{tabular}{|c|c|c|c|c|c|c|c|c|c|c|}
\hline & Mean & s.d. & I & 2 & 3 & 4 & 5 & 6 & 7 & 8 \\
\hline Short-term financial performance & 7.54 & 9.83 & 1.00 & & & & & & & \\
\hline Sustainability performance ${ }^{a}$ & 0.48 & 0.05 & $0.03 * * * * *$ & 1.00 & & & & & & \\
\hline Sustainability disclosure dummy ${ }^{a}$ & 0.51 & 0.50 & 0.03 ***十 & $0.7 \mid$ 米米米 & 1.00 & & & & & \\
\hline Sustainability disclosure ${ }^{\mathrm{a}}$ & 0.34 & 0.14 & -0.01 & $0.84 * * * *$ & $0.67 * * * *$ & 1.00 & & & & \\
\hline Current financial performance & 8.18 & 11.03 & $0.62 * * * *$ & $0.02 *$ & $0.02+$ & $0.02+$ & 1.00 & & & \\
\hline Size & 15.53 & 1.32 & $-0.16 * * * *$ & $0.44 * * * *$ & $0.34 * * * *$ & $0.4 \mid * * * *$ & $-0.14 * * * *$ & 1.00 & & \\
\hline Short-term risk exposure & -1.42 & 1.92 & $-0.05 * * * *$ & $0.09 * * * *$ & 0.10 ***** & $0.09 * * *$ & -0.05 ***** & $0.17 * * * *$ & 1.00 & \\
\hline
\end{tabular}

Number of observations $=10,814,{ }^{*} p<0.05, * * p<0.01, * * * p<0.001,+p<0.10$.

Long-term financial performance as the dependent variable

\begin{tabular}{|c|c|c|c|c|c|c|c|c|c|c|}
\hline & Mean & s.d. & 1 & 2 & 3 & 4 & 5 & 6 & 7 & 8 \\
\hline Long-term financial performance & 6.76 & 9.86 & 1.00 & & & & & & & \\
\hline Sustainability performance ${ }^{a}$ & 0.48 & 0.04 & 0.07 ****** & 1.00 & & & & & & \\
\hline Sustainability disclosure dummy a & 0.50 & 0.50 & $0.05^{* * * * * *}$ & $0.66^{*} * * *$ & 1.00 & & & & & \\
\hline Sustainability disclosure ${ }^{a}$ & 0.29 & 0.10 & 0.07 ******* & $0.89 * * * *$ & 0.73 ****** & 1.00 & & & & \\
\hline Current financial performance & 8.58 & 9.58 & 0.42 ****** & $0.04 * *$ & 0.02 & $0.08 * * *$ & 1.00 & & & \\
\hline Size & 15.50 & 1.34 & $-0.09 * * * *$ & $0.42^{* * * *}$ & 0.31 米米米 & $0.44 * * *$ & $-0.18 * * * *$ & 1.00 & & \\
\hline Short-term risk exposure & -1.43 & 1.81 & $-0.03 * *$ & $0.07^{* * * * *}$ & $0.10 * * * *$ & $0.09 * * *$ & $-0.04^{*} * * *$ & $0.19 * * *$ & 1.00 & \\
\hline Long-term risk exposure & -41.88 & 20.03 & $-0.12 * * * *$ & 0.09***** & 0.12 **** & $0.11 * * * *$ & $-0.28 * * * *$ & $0.28 * * *$ & $0.36 * * * *$ & 1.00 \\
\hline
\end{tabular}

Number of observations $=6,265$. $* p<0.05$, $* * * 0.01$, $* * * * * 0.001,+p<0.10$.

a The correlation between the sustainability performance and sustainability disclosure variables may be high but these variables are never included in the same model to prevent a multicollinearity issue.

Table 2. Descriptive statistics per year for sustainability performance and sustainability disclosure

\begin{tabular}{|c|c|c|c|c|c|c|}
\hline \multirow[t]{2}{*}{ Year } & \multicolumn{3}{|c|}{ Sustainability performance } & \multicolumn{3}{|c|}{ Sustainability disclosure } \\
\hline & $\begin{array}{c}\text { Number of } \\
\text { observations }\end{array}$ & Average & $\begin{array}{l}\text { Difference in means } \\
\text { (T-test between values } \\
\text { in } t \text { and values in } t-1)\end{array}$ & $\begin{array}{c}\text { Number of } \\
\text { observations }\end{array}$ & Average & $\begin{array}{l}\text { Difference in means } \\
\text { (T-test between values } \\
\text { in } t \text { and values in } t-1)\end{array}$ \\
\hline 2002 & 958 & 0.481 & & 958 & 0.267 & \\
\hline 2003 & 969 & 0.482 & 0.001 & 969 & 0.288 & $0.020 * * * *$ \\
\hline 2004 & 1,822 & 0.480 & -0.002 & 1,822 & 0.273 & -0.015 ***** \\
\hline 2005 & 2,239 & 0.480 & -0.001 & 2,239 & 0.296 & $0.023^{*} * * *$ \\
\hline 2006 & 2,252 & 0.480 & 0.001 & 2,252 & 0.308 & $0.01 \mid * * * *$ \\
\hline 2007 & 2,429 & 0.482 & 0.001 & 2,429 & 0.395 & $0.087 * * * *$ \\
\hline 2008 & 2,920 & 0.485 & 0.003 & 2,920 & 0.439 & $0.046 * * * *$ \\
\hline 2009 & 3,350 & 0.486 & 0.002 & 3,350 & 0.457 & $0.018 * * * *$ \\
\hline 2010 & 3,258 & 0.490 & $0.004 *$ & 3,258 & 0.475 & $0.018 * * * *$ \\
\hline
\end{tabular}

${ }^{*} p<0.05, * * * 0.01, * * * * p<0.001,+p<0.10$.

sometimes significant, were unstable (we observed strong variability of estimated coefficients when adding independent variables one by one - proof of strong remaining multicollinearity), and no strong instrument (correlated with sustainability performance but not with sustainability disclosure) could be found. To test hypotheses 3a-4b, we thus opted for a split sample methodology (Hansen, 2000; Jarque, 1987), which consisted of splitting our sample between firms with extensive and limited disclosure when running estimations that included sustainability performance as an independent 
variable. This allowed us to test our hypotheses without having both sustainability disclosure and sustainability performance as independent variables in the same estimations, thereby avoiding any risk of multicollinearity (models including both sustainability disclosure and performance as independent variables are only estimated as robustness tests). Although this method eliminated most endogeneity concerns related to reverse causality and multicollinearity, the results of our analysis should be treated with caution, as minor remaining endogeneity biases may still exist.

It is interesting to note in Table 2 that firms' sustainability performance can be considered statistically stable over the years, whereas their sustainability disclosure constantly increased every year. This preliminary result is in line with previous literature (Albertini, 2014) and gives partial support to our assumption that there exists an increasing institutional pressure from stakeholders for sustainability disclosure.

\section{Data analysis and results}

\section{Data analysis}

To test hypotheses I and 2, we used our sustainability disclosure measure as the independent variable and estimated its impact on firms' short- and long-term financial performance via two estimated models (models I and 2 ). In testing hypotheses 3a, 3b, 4a, and 4b, to cope with the inherent correlation between the sustainability disclosure and performance measures, we used the sustainability disclosure dummy to split our sample between firms with extensive sustainability disclosure (sustainability disclosure dummy equals I) and those with limited sustainability disclosure (sustainability disclosure dummy equals 0). For these two samples, we first estimated the impact of firms' sustainability performance on their short-term financial performance (models 3 and 4) and then on their longterm financial performance (models 4 and 5). The six estimated models are presented in Table 3.

Table 3. The impact of sustainability disclosure and sustainability performance on short- and long-term financial performance (as measured by return on assets)

\begin{tabular}{|c|c|c|c|c|c|c|}
\hline & $(\mathrm{I})$ & $(2)$ & (3) & (4) & (5) & (6) \\
\hline Dependent variable & $\begin{array}{l}\text { Short-term financial } \\
\text { performance }\end{array}$ & $\begin{array}{l}\text { Long-term financial } \\
\text { performance }\end{array}$ & \multicolumn{2}{|c|}{$\begin{array}{c}\text { Short-term financial } \\
\text { performance }\end{array}$} & \multicolumn{2}{|c|}{$\begin{array}{l}\text { Long-term financial } \\
\text { performance }\end{array}$} \\
\hline Screening criteria & None & None & $\begin{array}{c}\text { Extensive sustainability } \\
\text { disclosure }\end{array}$ & $\begin{array}{l}\text { Limited sustainability } \\
\text { disclosure }\end{array}$ & $\begin{array}{l}\text { Extensive sustainability } \\
\text { disclosure }\end{array}$ & $\begin{array}{l}\text { Limited sustainability } \\
\text { disclosure }\end{array}$ \\
\hline $\begin{array}{l}\text { Sustainability } \\
\text { disclosure }\end{array}$ & $\begin{array}{l}6.28 * * * * \\
(0.000)\end{array}$ & $\begin{array}{l}6.27 * * * * \\
(0.000)\end{array}$ & & & & \\
\hline $\begin{array}{l}\text { Sustainability } \\
\text { performance }\end{array}$ & & & $\begin{array}{l}9.52 * * * * 6 \\
(0.001)\end{array}$ & $\begin{array}{c}3.59 \\
(0.529)\end{array}$ & $\begin{array}{c}24.46 * * * * \\
(0.000)\end{array}$ & $\begin{array}{c}39.73 * * * * 6 \\
(0.000)\end{array}$ \\
\hline $\begin{array}{l}\text { Current financial } \\
\text { performance }\end{array}$ & $\begin{array}{l}0.14 * * * * \\
(0.000)\end{array}$ & $\begin{array}{c}0.03 * \\
(0.039)\end{array}$ & $\begin{array}{l}0.15^{* * * *} \\
(0.000)\end{array}$ & $\begin{array}{l}0.22 * * * * \\
(0.000)\end{array}$ & $\begin{array}{c}0.07 \text { ****** } \\
(0.000)\end{array}$ & $\begin{array}{l}0.12 \text { ***** } \\
(0.000)\end{array}$ \\
\hline Size & $\begin{array}{c}-\left.1.9\right|^{* * * * *} \\
(0.000)\end{array}$ & $\begin{array}{l}0.45 * * * * * \\
(0.000)\end{array}$ & $\begin{array}{c}-1.23^{* * * * *} \\
(0.000)\end{array}$ & $\begin{array}{c}-2.32 * * * * 1 \\
(0.000)\end{array}$ & $\begin{array}{l}-0.08 \\
(0.574)\end{array}$ & $\begin{array}{c}-0.75 * * * * 6 \\
(0.000)\end{array}$ \\
\hline $\begin{array}{l}\text { Short-term risk } \\
\text { exposure }\end{array}$ & $\begin{array}{c}0.06 \\
(0.188)\end{array}$ & $\begin{array}{l}-0.09 \\
(0.141)\end{array}$ & $\begin{array}{c}-0.16 \text { *** } \\
(0.007)\end{array}$ & $\begin{array}{l}0.15^{*} \\
(0.010)\end{array}$ & $\begin{array}{l}-0.15 \\
(0.169)\end{array}$ & $\begin{array}{l}-0.09 \\
(0.250)\end{array}$ \\
\hline $\begin{array}{l}\text { Long-term risk } \\
\text { exposure }\end{array}$ & & $\begin{array}{c}-0.02 * * \\
(0.003)\end{array}$ & & & $\begin{array}{c}-0.03 * * 6 \\
(0.002)\end{array}$ & $\begin{array}{c}0.01 \\
(0.699)\end{array}$ \\
\hline Year dummies & Yes & Yes & Yes & Yes & Yes & Yes \\
\hline Industry dummies & Yes & Yes & Yes & Yes & Yes & Yes \\
\hline Country dummies & Yes & Yes & Yes & Yes & Yes & Yes \\
\hline Constant & $\begin{array}{c}35.10 * * * * \\
(0.000)\end{array}$ & & $\begin{array}{c}22.87 * * * * \\
(0.000)\end{array}$ & $\begin{array}{c}39.90 * * * * 1 \\
(0.000)\end{array}$ & & \\
\hline Number of observations & $10,8 \mid 4$ & 6,265 & 5,481 & 5,333 & 3,143 & 3,122 \\
\hline Number of firms & 2,522 & ।,831 & ।,509 & ।,795 & 1,101 & 1,239 \\
\hline$R$-squared & 0.61 & 0.70 & 0.56 & 0.54 & 0.64 & 0.66 \\
\hline $\begin{array}{l}\text { Likelihood ratio } \\
\text { Chi-square }\end{array}$ & $1818 * * * *$ & $2112 * * * *$ & $673 * * * *$ & $648 * * *$ & $775 * * * *$ & $885 * * * *$ \\
\hline & $(0.000)$ & $(0.000)$ & $(0.000)$ & $(0.000)$ & $(0.000)$ & $(0.000)$ \\
\hline
\end{tabular}

Robust $p$-values are in parentheses. ${ }^{*} p<0.05, * *$, $p<0.01, * * * * 0.001,+p<0.10$. 
In models I and 2 that test hypotheses I and 2, a firm's sustainability disclosure is an independent variable. Model I considers a firm's short-term financial performance as the dependent variable, whereas Model 2 uses its long-term financial performance. Therefore, the only difference between models $I$ and 2 is that when sustainability disclosure is measured in the focal year $n$ (as an example, 2004), the dependent variable in Model I (short-term financial performance) is the average ROA of a firm in years $n+1$ and $n+2$ (in the example, 2005 and 2006), whereas in Model 2, the dependent variable (long-term financial performance) is the average ROA of a firm in years $n+3$ and $n+4$ (in the example, 2007 and 2008).

Next, models 3 and 4 test hypotheses $3 \mathrm{a}$ and 3b. These two models contain sustainability performance as an independent variable and short-term financial performance as the dependent variable. They are estimated on two subsamples. Model 3 is estimated on a sample that only contains firms with extensive sustainability disclosure (thus testing hypothesis 3a), whereas Model 4 is estimated on a sample that only considers firms with limited sustainability disclosure (thus testing hypothesis 3b).

Finally, models 5 and 6, which test hypotheses $4 a$ and $4 b$, also consider a firm's sustainability performance as the independent variable and the long-term financial performance as the dependent variable. Models 5 and 6 are also estimated on two subsamples. Model 5 only includes firms with extensive disclosure (thus testing hypothesis 4a), whereas Model 6 only considers firms with limited disclosure (thus testing hypothesis $4 \mathrm{~b}$ ).

Models 1-6 were estimated through a maximum likelihood random effect estimation, including control variables, country, industry, and year dummies, and estimations robust to heteroskedasticity. Models I-6 all used panel longitudinal data. Due to the forward-looking component of the dependent variables, in models 1,3 , and 5 , the independent variables are measured over the 2002-2008 period and the dependent variables are measured over the 2003-2010 period. Similarly, in models 2, 4, and 6, the independent variables belong to the 2002-2006 period and the dependent variables belong to the 2005-20l 0 period. In those latter models, we also dropped the constant terms, which were not significant. The random effect, control variables, and industry, country, and year dummies allow us to control for any sample selection bias that may arise from the split in models 3, 4, 5, and 6 between firms with limited and extensive sustainability disclosure.

\section{Results}

Model I underlines that sustainability disclosure directly and positively influences short-term financial performance (coefficient equals 6.28 with a $p$-value below $0.1 \%$, which shows a very high probability of observing the effect). Model 2 shows that the extent of sustainability disclosure also positively and significantly impacts long-term financial performance (coefficient equals 6.27 and is significant with a $p$-value below $0.1 \%$ ). Model I, therefore, robustly validates hypothesis I, and Model 2 robustly supports hypothesis 2 . The conformity mechanism is effective in both the short and long run: firms gain stakeholder support, legitimacy, and higher financial performance from extensive sustainability disclosure.

Model 3 shows that for firms with extensive sustainability disclosure, the impact of sustainability performance on shortterm financial performance is positive (9.52), with a high probability of being observed within the sample ( $p$-value lower than $0.1 \%$ ). However, Model 4 shows that for firms with limited sustainability disclosure, the impact of sustainability performance on short-term financial performance is not significant ( $p$-value of $52.9 \%$ ). Model 3, therefore, validates hypothesis 3a, and Model 4 validates hypothesis 3b. Model 3 shows that firms with extensive sustainability disclosure reveal their achieved sustainability performance and allow stakeholders to value their sustainability investments (positive and significant coefficient). The short-term financial performance of firms with extensive disclosure is positively impacted when their sustainability performance increases (hypothesis 3a). On the contrary, Model 4 shows that firms with limited sustainability disclosure leave their stakeholders in doubt. Thus, their short-term financial performance does not benefit from high levels of sustainability (insignificant coefficient) but also does not suffer from poor sustainability results (hypothesis 3b). Therefore, models 3 and 4 show that the revelation mechanism is effective in the short term.

Models 5 and 6, however, show that both subsamples of firms with extensive and limited sustainability disclosure have a positive and significant impact on their long-term financial performance with increasing sustainability performance (coefficients are, respectively, 24.46 and 39.73, with both $p$-values below $0.1 \%$, which shows a high probability of observing the effects). Therefore, Model 5 validates hypothesis 4a, and Model 6 validates hypothesis $4 \mathrm{~b}$. In the long term, the revelation mechanism is not effective and sustainability disclosure does not moderate the relationship between sustainability performance and financial performance, but stakeholders are able to evaluate the degree of the sustainability performance of all firms, even those with limited sustainability disclosure. As a consequence, firms with low sustainability performance cannot avoid being penalized for their poor sustainability results, even when trying to hide them with limited sustainability disclosure.

To illustrate the predicted and confirmed effects of hypotheses I, 2, 3a, 3b, 4a, and 4b on firms' financial performance, we generated the predictions of models $1-6$ over the whole sample of firms and with all independent variables other than sustainability disclosure and sustainability performance set at 
their mean. We generated those predictions over the whole sample of firms to provide illustrations that cope with the latent dynamic that exists in our data set: firms have a tendency to implement either a high sustainability performance/extensive sustainability disclosure strategy or a low sustainability performance/limited sustainability disclosure strategy. When Model 3, as an example, is only estimated over the subsample of firms with extensive sustainability disclosure (5,48I observations), those firms most likely have higher sustainability performance. By generating the predictions of Model 3 over the whole sample of firms, we illustrate the short-term financial performance of firms that actually adopted a low sustainability performance/ limited sustainability disclosure strategy but hypothetically adopted a low sustainability performance/extensive sustainability disclosure strategy. In other words, the predictions of Model 3 over the whole sample of firms estimate the achieved shortterm financial performance of firms with extensive disclosure for all potential values of sustainability performance (not just high values). The predictions of models 1-6 over the whole sample of firms and with all independent variables other than sustainability disclosure and sustainability performance set at their mean values are presented in Figures $1-3$.

Figure I relates to hypotheses I and 2 (models I and 2) and illustrates the conformity mechanism. It shows that conformity to the norms of disclosure (increased sustainability disclosure) has a positive impact on short- and long-term financial performance. Figures 2 and 3 relate to hypotheses 3a, 3b, 4a, and $4 b$ (models 3-6) and illustrate the revelation mechanism. Figure 2 shows that the revelation mechanism is effective in the short term: firms with low sustainability performance are able to mislead their stakeholders about their poor sustainability results with limited sustainability disclosure, whereas firms with high sustainability performance reap benefits by revealing their positive results to stakeholders. Figure 3 shows that both lowand high-sustainability performance firms achieve higher longterm financial performance when their sustainability disclosure is extensive, which reveals that the revelation mechanism is not effective in the long term, unlike the conformity mechanism. In other words, firms gain by conforming to the norm of transparency and cannot hide their poor results under limited sustainability disclosure.

\section{Robustness checks}

Although our models strongly support hypotheses I-4, we further tested the robustness of the results for statistical and cognitive biases. We first checked for any multicollinearity issues. The variance inflation factor (VIF) of variables ranges from 1.03 to 9.43 , and the mean VIF of models ranges from 1.56 to 3.12 . Such results allow us to confirm the nonexistence of a multicollinearity bias.

Second, to evaluate whether sustainability performance may create an omitted variable bias in models I and 2, we estimated those models including the sustainability performance measure as a control variable (results not reported). This robustness test validates hypotheses I and 2 (conformity

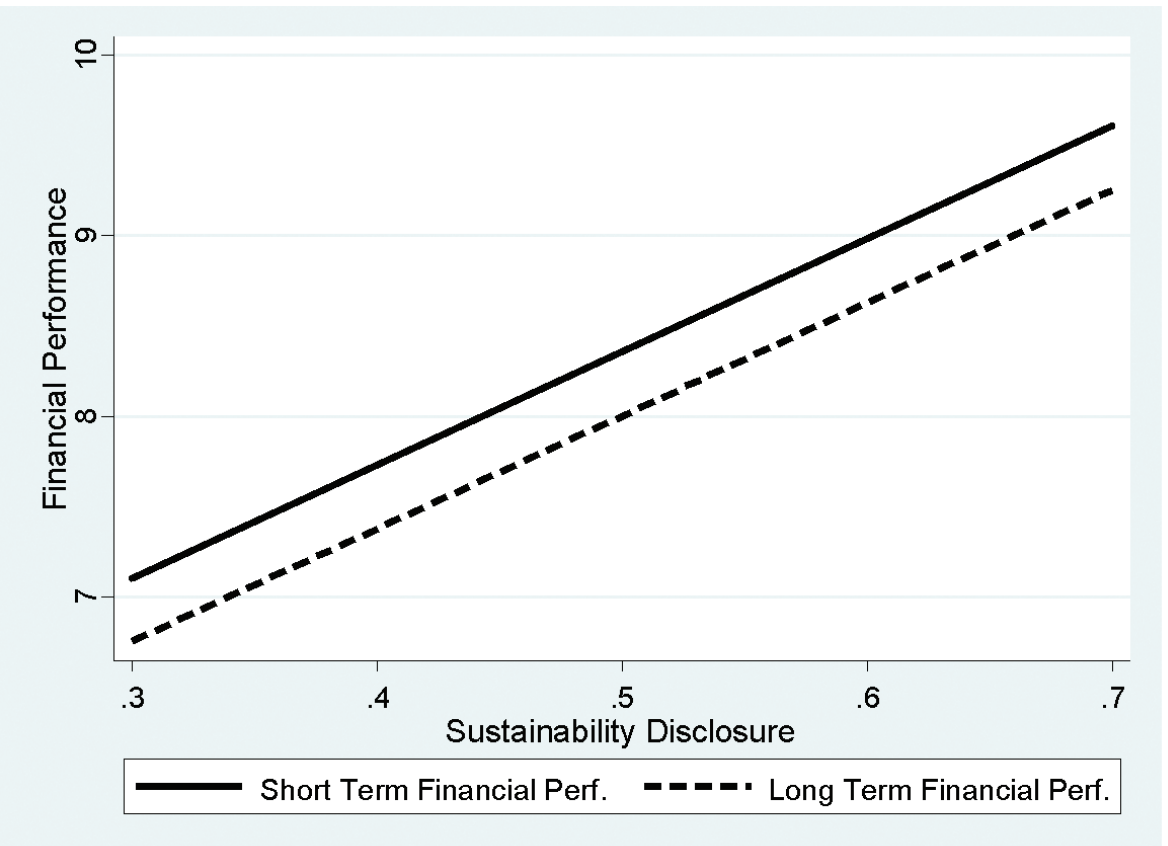

Figure I. Predicted impact of sustainability disclosure on short- and long-term financial performance of the firm 


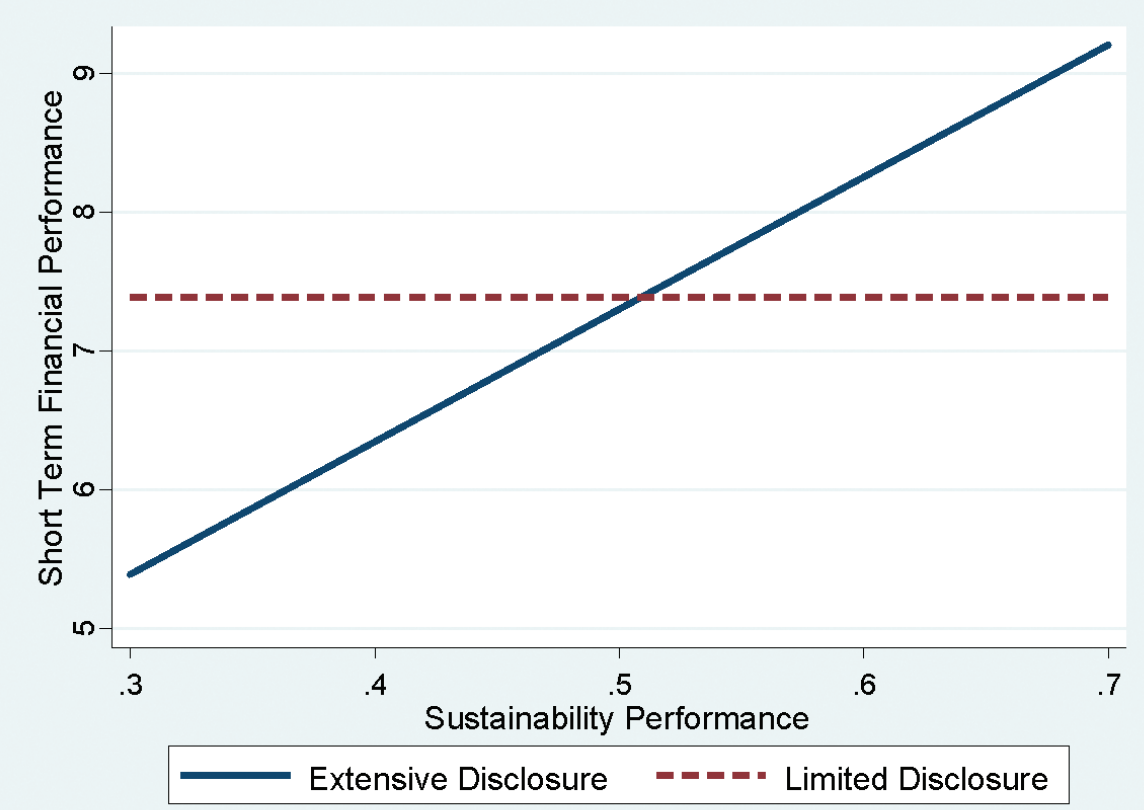

Figure 2. Predicted short-term financial performance of firms with extensive and limited sustainability disclosure

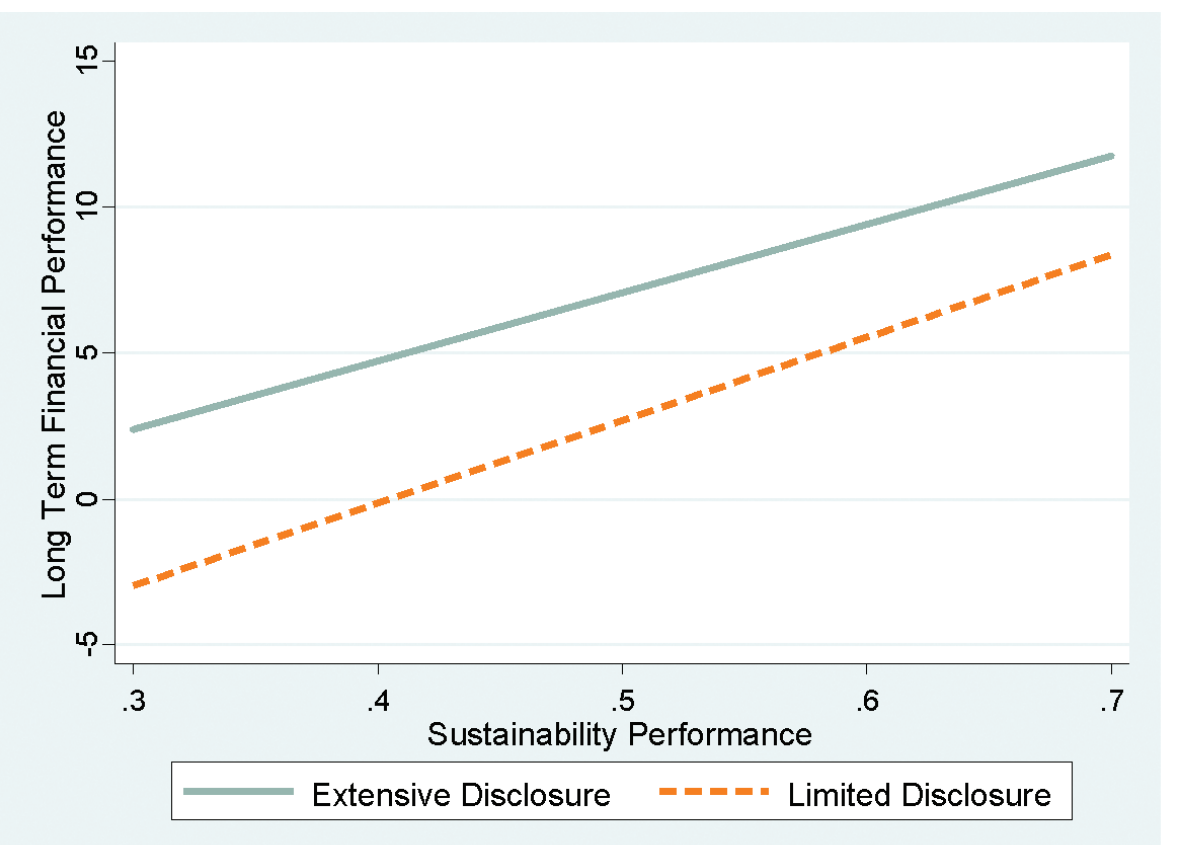

Figure 3. Predicted long-term financial performance of firms with extensive and limited sustainability disclosure

mechanism efficiency in the short and long term) and supports our results. These two models can, however, only be considered robustness tests, as they bear, as expected, the risk of bias due to multicollinearity between the sustainability performance and sustainability disclosure measures (VIF > 20). They, therefore, provide further justification for our decision to use a split sample methodology to test the revelation mechanism (models 3 to 6 of Table 3). 
Third, following previous studies that used market-based measures as a proxy for a firm's financial performance instead of its return on assets (Flammer, 2013; Surroca et al., 2010; Wang, Choi, \& Li, 2008), we estimated models I-6 with Tobin's $Q^{10}$ as the dependent variable to indicate firms' financial performance. Results of those estimations (not reported here) are similar in range, sign, and significance and also validate hypotheses $1-4$.

Fourth, prior literature also suggested that institutional pressures for sustainability may vary between countries (Spencer \& Gomez, 2011; Van der Laan Smith, Adhikari, Tondkar, \& Andrews, 2010) and that because regulatory frameworks are diverse, firms (depending on their country of incorporation) may have an incentive to invest in sustainability and its reporting (Baldini et al., 2018; Holland \& Boon Foo, 2003; Surroca, Tribo, \& Zahra, 2013 ). To test if our hypotheses are resilient to between-countries differences in norms and regulations, we run models $1-6$ but, this time, identify firms with extensive or limited disclosure at the country level by splitting our initial sample at the median of firms' sustainability disclosure not only per year but also per country. In doing so, we split our sample for each year between firms with extensive disclosure compared to other firms in their own country and those with limited disclosure compared to their peers in their own country. By doing so, we considered country-specific regulations and institutional pressures while maintaining the extent of our data set. The results (not reported here) are similar in range, sign, and significance, and, therefore, hypotheses $1-4$ are again validated. Although their amplitude might vary across countries, the conformity and revelation mechanisms are effective within countries that constitute our sample. To additionally check the robustness of our results against country-specific frameworks, we run models $1-6$ including only firms with US- and Canada-based headquarters (996 firms in our data set), considering that these two countries have similar regulatory and institutional frameworks regarding sustainability and its disclosure. The results (not reported here) also support hypotheses I-4, which are valid when only one institutional framework is considered.

Fifth, the same argument of heterogeneity of norms, regulations, and activists' pressures among countries could be made regarding industries. Institutional pressures for higher sustainability performance and disclosure vary among industries (Herz \& Rogers, 2016; Reid \& Toffel, 2009; Rodriguez et al., 2017), and this could influence our results. To test if our hypotheses are resilient to between-industries differences in norms and regulations, we run models $1-6$, splitting our initial samples at the median of firms' sustainability disclosure per year (as in our initial models), as well as per industry. We identified for each year firms with extensive sustainability

\footnotetext{
$\overline{\text { 10. (Market capitalization }}+$ net debt)/total assets.
}

disclosure and those with limited sustainability disclosure compared to their industry peers. The results (not reported here) are similar in range, sign, and significance and thus validate hypotheses $1-4$.

Finally, although hypotheses I-4 seem strongly and robustly validated, both by our initial model and robustness tests, it is important to note that our study considers sustainability disclosure as a whole, not differentiating disclosure of social performance, environmental performance, and effective governance (Chatterji et al., 20l6; Mahadeo et al., 20l I). We showed in this study that sustainability disclosure participates in a conformity mechanism that has short- and long-term effects on financial performance and in a revelation mechanism that is only effective in the short term in moderating the relationship between sustainability performance and financial performance. However, one could argue that environmental, social, and governance disclosure may have diverging effects. Although such research questions may inspire future works, as a robustness check, we estimated models $1-6$ considering only the environmental performance and disclosure of firms as measured by ASSET4 as our independent variables. Results of these estimations (not reported here) also support hypotheses $1-4$ in the environmental component and thus provide further support for our theoretical framework.

\section{Discussion and conclusion}

This study investigates the relationships among firms' sustainability disclosure, sustainability performance, and financial performance. It specifically argues that firms, by adjusting the extent of their sustainability disclosure, trigger two mechanisms that have different effects on stakeholder support and financial performance: the conformity mechanism, within which a firm gains stakeholder support and legitimacy by showing conformity to the norms of disclosure, and the revelation mechanism, within which a firm either reassures or leaves its stakeholders in doubt about its actual sustainability performance. We theorize on the efficiency of these mechanisms and their impact on financial performance in both the short and long terms. We first show that the conformity mechanism is effective in both the short and long terms: extensive sustainability disclosure elicits stakeholder support, shows conformity to the disclosure norms, and, thereby, positively impacts financial performance both in the short and long runs. We also show that the revelation mechanism is effective only in the short term: sustainability performance impacts firms' short-term financial performance only when they opt for extensive disclosure. Therefore, higher sustainability performers have an interest in extensive disclosure, whereas weak performers are more likely to give noisy signals via their disclosure in the short run. However, in the long term, stakeholders are able to evaluate a firm's sustainability 
performance, even when the firm adopts limited disclosure. Therefore, the revelation mechanism is not effective in the long term, i.e. sustainability disclosure does not moderate the relationship between sustainability performance and financial performance in the long term). Hence, even for firms with limited disclosure, sustainability performance has an effect on their long-term financial performance. In other words, firms cannot strategically use sustainability disclosure to hide low sustainability performance and leave stakeholders in doubt in the long term.

We contribute to three streams of literature. First, we contrast and reconcile two theoretical perspectives in sustainability disclosure: legitimacy theory, which underlines the existence of pressure for conformity to the norms of disclosure (Mahadeo et al., 20 I I; Philippe \& Durand, 20 I I; Reid \& Toffel, 2009), and signaling theory, which sees disclosure as a way for a firm to reveal or hide some underlying characteristics of interest (King et al., 2005; Mahoney et al., 20 I3). By showing that both mechanisms, which derived from these two theories, exist on different time horizons, we hope to advance the understanding of the relationship between sustainability disclosure and sustainability performance (Cho et al., 2015; Hummel \& Schlick, 2016; Mahoney et al., 2013). Second, our findings provide useful insights into the largely unexplored relationship between sustainability disclosure and corporate financial performance (Eccles et al., 2014; Rodriguez et al., $2017)$ by defining how disclosure might have direct and indirect effects that lead to financial benefits. Finally, we hope to contribute to the long-standing stream of literature on the effect of sustainability performance on financial performance (Barnett \& Salomon, 2006; Busch \& Friede, 2018; McWilliams \& Siegel, 2000). Given that most prior works and data analyses focused on the short-term consequences of business sustainability (Ortiz-de-Mandojana \& Bansal, 20 I 6), we hope to shed light on the long-term effects of sustainability performance and the strategic use of sustainability disclosure by firms in the relationship between sustainability performance and financial performance within the boundaries of a time frame.

\section{Managerial implications}

For managers, the choice of the extent of sustainability disclosure is not evident, as they may face obstacles as a result of the opposite effects of the conformity and revelation mechanisms. For instance, firms with poor sustainability results may benefit from extensive disclosure, showing stakeholders that they respond to their demand for transparency (conformity mechanism), but they may be punished for the poor sustainability performance they disclose (revelation mechanism). Unsustainable firms may hide their detrimental impact on society and the environment when they focus on short-term financial performance, thereby benefitting from the revelation mechanism. In the long run, however, if a firm's sustainability performance is not positive, managers cannot secure stakeholders' support and a positive financial return from their sustainability investments.

Moreover, employing sustainability disclosure to manage the public perception of a firm's sustainability performance (Deegan, 2002) is becoming increasingly difficult. Firms that are in institutional contexts in which they are more exposed to scrutiny and global norms are less capable of strategically limiting their sustainability disclosure, especially with the growing civil society activism and information access (Marquis et al., 2016). As investors increasingly incorporate sustainability disclosure in decision-making, the importance of extensive disclosure will also grow (Rodriguez et al., 2017). Hence, for managers, choosing to invest in sustainability and trying to increase the sustainability performance of their companies, as well as communicating extensively on the topic, appears to be the best choice.

\section{Acknowledgements}

The authors would like to thank the anonymous reviewers as well as the associate editor, Simon Porcher, for their valuable feedbacks that helped significantly improve this article.

\section{Conflicts of interest}

None.

\section{References}

Aguinis, H. \& Glavas, A. (2012). What we know and don't know about corporate social responsibility: A review and research agenda. Journal of Management, 38(4), 932-968. doi: | 0. I | 77/0 | 492063 | | 436079

Akerlof, G. A. (1970). The market for "Lemons": Quality uncertainty and the market mechanism. Quarterly Journal of Economics, 84(3), 488-500. doi: | 0.2307/| 87943|

Albertini, E. (2014). A descriptive analysis of environmental disclosure: A longitudinal study of French companies. Journal of Business Ethics, 121 , 233-254. doi: I0. I007/s I055 I-0 I3-1698-y

Baldini, M., Maso, L. D., Liberatore, G., Mazzi, F. \& Terzani, S. (20 I8). Role of country- and firm-level determinants in environmental, social, and governance disclosure. Journal of Business Ethics, I 50(I),79-98. doi: I0. I007/ sl0551-016-3139-1

Barnett, M. L. \& Salomon, R. M. (2006). Beyond dichotomy:The curvilinear relationship between social responsibility and financial performance. Strategic Management Journal, 27( I I), I I 0 I- | I 22. doi: I 0. I 002/smj.557

Barney, J. B. \& Hansen, M. H. (1994). Trustworthiness as a source of competitive advantage. Strategic Management Journal, 15, 175-190. doi: | 0. I002/smj.42501509|2

Benlemlih, M., Shaukat, A., Qiu, Y. \& Trojanowski, G. (20 I 8). Environmental and social disclosures and firm risk. Journal of Business Ethics, 152(3), 6|3-626. doi: | 0. I007/s |055 I-0 |6-3285-5

Beretta, S. \& Bozzolan, S. (2008). Quality versus quantity: The case of forward-looking disclosure. Journal of Accounting, Auditing \& Finance, 23(3), 333-375. doi: I 0.1 I 77/0 | 48558X0802300304 
Burritt, R. L. \& Schaltegger, S. (20I0). Sustainability accounting and reporting: Fad or trend? Accounting, Auditing \& Accountability Journal, 23(7), 829-846. doi: I0.1 108/095 I 357| 011080144

Busch, T. \& Friede, G. (20।8). The robustness of the corporate social and financial performance relation: A second-order meta-analysis. Corporate Social Responsibility and Environmental Management, 25(4), 583-608. doi: I0.1 1002/csr. 1480

Cavaco, S. \& Crifo, P. (20 I4). CSR and financial performance: Complementarity between environmental, social and business behaviours. Applied Economics, 46(27), 3323-3338. doi: I0. I080/00036846.20।4.927572

Cespa, G. \& Cestone, G. (2007). Corporate social responsibility and managerial entrenchment. Journal of Economics \& Management Strategy, | 6(3), 74|-77|. doi: | 0.1 | ||/j. I530-9|34.2007.00|56.x

Chatterji, A. K., Durand, R., Levine, D. I. \& Touboul, S. (20।6). Do ratings of firms converge? Implications for managers, investors and strategy researchers. Strategic Management Journal, 37(8), |597-16|4. doi: $10.1002 / \mathrm{smj} .2407$

Cheng, B., loannou, I. \& Serafeim, G. (2014). Corporate social responsibility and access to finance. Strategic Management Journal, 35(I), I-23. doi: $10.1002 / \mathrm{smj} .2131$

Cho, C. H.., Guidry, R. P., Hageman, A. M. \& Patten, D. M. (20।2). Do actions speak louder than words? An empirical investigation of corporate environmental reputation. Accounting, Organizations \& Society, 37(I), | 4-25. doi: 10.1016/j.aos.201 I.12.00 I

Cho, C. H., Laine, M., Roberts, R. W. \& Rodrigue, M. (20I5). Organized hypocrisy, organizational Façades, and sustainability reporting. Accounting, Organizations \& Society, 40, 78-94. doi: I 0.1 0 I6/j.aos.20 I4. I2.003

Cho, C. H., Laine, M., Roberts, R. W. \& Rodrigue, M. (20। 8). The frontstage and backstage of corporate sustainability reporting: Evidence from the Arctic National Wildlife Refuge Bill. Journal of Business Ethics, 152(3), 865-886. doi: | 0. I007/s | 055 I-0 | 6-3375-4

Cho, C. H. \& Patten, D. M. (2007). The role of environmental disclosures as tools of legitimacy: A research note. Accounting, Organizations \& Society, 32(7/8), 639-647. doi: 10.1016/j.aos.2006.09.009

Cho, C. H., Roberts, R. W. \& Patten, D. M. (20I0). The language of US corporate environmental disclosure. Accounting, Organizations \& Society, 35(4), 43 I-443. doi: I 0. I 0 I6/j.aos.2009. 10.002

Choi, J. \& Wang, H. (2009). Stakeholder relations and the persistence of corporate financial performance. Strategic Management Journal, 30(8), 895-907. doi: 10.1002/smj.759

Clarkson, G. \& Toh, P. K. (20 I0). “Keep Out” signs: The role of deterrence in the competition for resources. Strategic Management Journal, 3 I ( I I), I202-I225. doi: I0. I002/smj.853

Clarkson, P. M., Li, Y., Richardson, G. D. \& Vasvari, F. P. (2008). Revisiting the relation between environmental performance and environmental disclosure: An empirical analysis. Accounting, Organizations \& Society, 33(4/5), 303-327. doi: 10.10 16/j.aos.2007.05.003

Connelly, B. L., Certo, S. T., Ireland, R. D. \& Reutzel, C. R. (20I I). Signaling theory: A review and assessment. Journal of Management, 37(I), 39-67. doi: 10.1 177/0149206310388419

Cormier, D. \& Magnan, M. (1999). Corporate environmental disclosure strategies: Determinants, costs and benefits. Journal of Accounting, Auditing \& Finance, | 4(4),429-45 I. doi: | 0.1 | 77/0 | 48558X990 | 400403

Criado-Jiménez, I., Fernández-Chulián, M., Larrinage-González, C. \& Husillos-Carqués, F. (2008). Compliance with mandatory environmental reporting in financial statements:The case of Spain (200I-2003). Journal of Business Ethics, 79(3), 245-262. doi: I 0. I 007/s I 055 I-007-9375-7

Cui, J., Jo, H. \& Na, H. (2018). Does corporate social responsibility affect information asymmetry? Journal of Business Ethics, 148(3), 549-572. doi: 10.1007/s | 055 I-015-3003-8
Deegan, C. (2002). Introduction: The legitimising effect of social and environmental disclosures: A theoretical foundation. Accounting, Auditing \& Accountability Journal, 15(3), 282-311. doi: I0.1 1 08/095 I 35702 I0435852

Deephouse, D. L. (1996). Does isomorphism legitimate? Academy of Management Journal, 39(4), 1024-1039. doi: 10.2307/256722

Delmas, M. A. \& Burbano, V. C. (20I I). The drivers of greenwashing. California Management Review, 54(I), 64-87. doi: I0.1525/cmr.20 II. 54.1.64

Dessain, V., Meier, O. \& Salas, V. (2008). Corporate governance and ethics: Shareholder reality, social responsibility or institutional necessity? M@n@ gement, I / (2), 65-79. doi: I0.39 I7/mana. I 12.0065

Eccles, R. G., loannou, I. \& Serafeim, G. (2014). The impact of corporate sustainability on organizational processes and performance. Management Science, 60(I I), 2835-2857. doi: 10.1287/mnsc.2014.1984

Flammer, C. (20 I3). Corporate social responsibility and shareholder reaction:The environmental awareness of investors. Academy of Management Journal, 56(3), 758-78I. doi: I0.5465/amj.20 I I.0744

Freeman, R. E. \& Reed, D. L. (1983). Stockholders and stakeholders: A new perspective on corporate governance. California Management Review, 25(3), 88-106. doi: |0.2307/4| I650। 8

Ginzel, L. E., Kramer, R. M. \& Sutton, R. I. (1992). Organizational impression management as a reciprocal influence process: The neglected role of the organizational audience. Research in Organizational Behavior, 15, 227.

Gray, R. (1992). Accounting and environmentalism: An exploration of the challenge of gently accounting for accountability, transparency and sustainability. Accounting, Organizations \& Society, 17(5), 399-425. doi: $10.1016 / 036 \mid-3682(92) 90038-T$

Gray, R. \& Milne, M. (2002). Sustainability reporting:Who's kidding whom? Chartered Accountants Journal, 8I (6), 66-70.

Greve, H. R. (20I I). Fast and expensive: The diffusion of a disappointing innovation. Strategic Management Journal, 32(9), 949-968. doi: I0. I002/ smj.922

Guidry, R. P. \& Patten, D. M. (20 I0). Market reactions to the first-time issuance of corporate sustainability reports: Evidence that quality matters. Sustainability Accounting, Management and Policy Journal, I(I), 33-50. doi: I0.1 I08/2040802 I01 I059214

Hahn, R. \& Lülfs, R. (2014). Legitimizing negative aspects in GRI-oriented sustainability reporting: A qualitative analysis of corporate disclosure strategies. Journal of Business Ethics, 123(3), 40I-420. doi: 10.1007/ sl055|-0|3-|80|-4

Hansen, B. E. (2000). Sample splitting and threshold estimation. Econometrica, 68(3), 575-603. doi: 10.1 I | |/1468-0262.00 I24

Hawn, O. \& loannou, I. (20।6). Mind the gap:The interplay between external and internal actions in the case of corporate social responsibility. Strategic Management Journal, 37( I3), 2569-2588. doi: I 0. I 002/smj.2464

Herz, B. \& Rogers, J. (2016). Measuring what matters: Industry specificity helps companies and investors gain traction on sustainability. Journal of Applied Corporate Finance, 28(2), 34-38.

Hillman, A. J. \& Keim, G. D. (200I). Shareholder value, stakeholder management, and social issues: What's the bottom line? Strategic Management Journal, 22(2), I25-139. doi: I0.1002/I097-0266(200 I O I)22:2\%3C I25:: AID-SMJI 50\%3E3.0.CO;2-H

Holland, L. \& Boon Foo,Y. (2003). Differences in environmental reporting practices in the UK and the US: The legal and regulatory context. British Accounting Review, 35(I), I-18. doi: I0.1016/S0890-8389(02) $00127-0$

Huang, C.-L. \& Kung, F.-H. (20 I 0). Drivers of environmental disclosure and stakeholder expectation: Evidence from Taiwan. Journal of Business Ethics, 96(3), 435-45 I. doi: I0. I 007/s I 055 I-0 I 0-0476-3 
Hull, C. E. \& Rothenberg, S. (2008). Firm performance:The interactions of corporate social performance with innovation and industry differentiation. Strategic Management Journal, 29(7), 781-789. doi: 10.1002/ smj. 675

Hummel, K. \& Schlick, C. (2016). The relationship between sustainability performance and sustainability disclosure: Reconciling voluntary disclosure theory and legitimacy theory. Journal of Accounting and Public Policy, 35(5), 455-476. doi: I 0. I 0 I6/j.jaccpubpol.2016.06.00 I

Ingram, R. W. (1978). An investigation of the information content of (certain) social responsibility disclosures. Journal of Accounting Research, I 6(2), 270-285. doi: I 0.2307/2490567

loannou, I. \& Serafeim, G. (20I5). The impact of corporate social responsibility on investment recommendations: Analysts' perceptions and shifting institutional logics. Strategic Management Journal, 36(7), I053-108I. doi: $10.1002 / \mathrm{smj} .2268$

Jaggi, B. \& Freedman, M. (1992). An examination of the impact of pollution performance on economic and market performance: Pulp and paper firms. Journal of Business Finance \& Accounting, 19(5), 697-713. doi: 10.1 | | |/j. 1 468-5957.1992.tb00652.x

Jarque, C. M. (1987). Sample splitting and applied econometric modeling. Journal of Business \& Economic Statistics, 5(2), 267-274. doi: I0. I080/07 350015.1987 .10509585

Jiang, R. J. \& Bansal, P. (2003). Seeing the need for ISO I400I. Journal of Management Studies, 40(4), I047-1067. doi: I 0.1 I I I/ |467-6486.00370

Jones, T. M. (1995). Instrumental stakeholder theory: A synthesis of ethics and economics. Academy of Management Review, 20(2), 404-437. doi: 10.5465/amr. 1995.9507312924

Kim, E.-H. \& Lyon,T.P. (20I5). Greenwash vs. Brownwash: Exaggeration and undue modesty in corporate sustainability disclosure. Organization Science, 26(3), 705-723. doi: I0.1287/orsc.2014.0949

King, A. \& Toffel, M.W. (2009). Self-regulatory institutions for solving environmental problems: Perspectives and contributions from the management literature. In M. Delmas \& O. R. Young (Eds.), Governance for the environment: New perspectives (pp. 98-I I 5). Cambridge, UK: Cambridge University Press.

King, A. A., Lenox, M. J. \& Terlaak, A. (2005). The strategic use of decentralized institutions: Exploring certification with the ISO 1400 I management standard. Academy of Management Journal, 48(6), I09 I-I 106. doi: |0.5465/amj.2005. 19573 | I |

Kolk, A., van derVeen, M., Hay, K. \& Wennink, D. (2002). KPMG international survey of corporate sustainability reporting. De Meern: KMPG.

KPMG. (20II). KPMG international corporate responsibility reporting survey 201 I. New York, NY: KPMG. Retrieved from https://home.kpmg/ru/en/ home/insights/2012/02/international-survey-of-corporate-responsibility-reporting.html

Lyon,T. \& Kim, E. (2007). Greenhouse gas reductions or greenwash? The DOE's 1605b Program. University of Michigan, mimeo, April.

Mahadeo, J., Oogarah-Hanuman, V. \& Soobaroyen, T. (20I I). A longitudinal study of corporate social disclosures in a developing economy. Journal of Business Ethics, I 04(4), 545-558. doi: I 0. I 007/s I 055 I-0 I I-0929-3

Mahoney, L. S., Thorne, L., Cecil, L. \& LaGore, W. (20।3). A research note on standalone corporate social responsibility reports: Signaling or greenwashing? Critical Perspectives on Accounting, 24(4), 350-359. doi: I0.1 0 | 6/j.cpa.20 I2.09.008

Marquis, C., Toffel, M.W. \& Yanhua, Z. (2016). Scrutiny, norms, and selective disclosure: A global study of greenwashing. Organization Science, 27(2), 483-504. doi: 10.1287/orsc.2015.1039

McGee, P. (2017). How VW's cheating on emissions was exposed. Financial Times. Online article, January II. Retrieved from https://www.ft.com/ content/ I 03dbe6a-d7a6-I l e6-944b-e7eb37a6aa8e
McWilliams, A. \& Siegel, D. (2000). Corporate social responsibility and financial performance: Correlation or misspecification? Strategic Management Journal, 2 I (5), 603-609. doi: I0.1002/(SICl) I097-0266 (200005)21:5\%3C603::AID-SMJ I 01\%3E3.0.CO;2-3

Michelon, G. (20I I). Sustainability disclosure and reputation: A comparative study. Corporate Reputation Review, 14(2), 79-96. doi: 10.1057/ crr.2011.10

Milgrom, P. \& Roberts, J. (1982). Predation, reputation and entry deterrence. Journal of Economic Theory, 27(2), 280-3 I 2. doi: I 0. I 1 l 6/0022-053 I (82) 90031-X

Milgrom, P. \& Roberts, J. (1986). Price and advertising signals of product quality. Journal of Political Economy, 94(4), 796-82 I. doi: I0.1086/26। 408

Navis, C. \& Glynn, M. A. (2010). How new market categories emerge: Temporal dynamics of legitimacy, identity, and entrepreneurship in satellite radio, 1990-2005. Administrative Science Quarterly, 55(3), 439-47I. doi: I0.2 I 89/asqu.2010.55.3.439

Ortiz-de-Mandojana, N. \& Bansal, P. (2016). The long-term benefits of organizational resilience through sustainable business practices. Strategic Management Journal, 37(8), 1615-1631. doi: 10.1002/smj.2410

Patten, D. M. (2002). The relation between environmental performance and environmental disclosure: A research note. Accounting, Organizations \& Society, 27(8), 763-773. doi: 10.1016/50361-3682(02)00028-4

Philippe, D. \& Durand, R. (20I I). The impact of norm-conforming behaviors on firm reputation. Strategic Management Journal, 32(9), 969-993. doi: $10.1002 /$ smj.919

Plumlee, M., Brown, D., Hayes, R. M. \& Marshall, R. S. (20 I5). Voluntary environmental disclosure quality and firm value: Further evidence. Journal of Accounting and Public Policy, 34(4), 336-36I. doi: I0. I 01 6/j.jaccpubpol. 2015.04 .004

Ragozzino, R. \& Reuer, J. J. (20I I). Geographic distance and corporate acquisitions: Signals from IPO firms. Strategic Management Journal, 32(8), 876-894. doi: 10.1002/smj.914

Reid, E. M. \& Toffel, M.W. (2009). Responding to public and private politics: Corporate disclosure of climate change strategies. Strategic Management Journal, 30( I I), I I57-I I 78. doi: I0. I002/smj.796

Reimsbach, D. \& Hahn, R. (20।5). The effects of negative incidents in sustainability reporting on investors' judgments: An experimental study of thirdparty versus self-disclosure in the realm of sustainable development. Business Strategy \& the Environment, 24(4), 217-235. doi: I0.1002/bse. 1816

Rodriguez, A., Cotran, H. \& Stewart, L. S. (2017). Evaluating the effectiveness of sustainability disclosure: Findings from a recent SASB study. Journal of Applied Corporate Finance, 29(2), I00-108. doi: 10.1 I I //jacf. I 2237

Röhrbein, N. (20 I 0). BP, investors' blind spot, IPE. Online article, September. Retrieved from https://www.ipe.com/analysis/analysis/bp-investorsblind-spot/3664l article

Roulet, T. J. \& Touboul, S. (2015). The intentions with which the road is paved: Attitudes to liberalism as determinants of greenwashing. Journal of Business Ethics, I 28(2), 305-320. doi: I 0. I 007/s I 055 I-0 |4-2097-8

Schaltegger, S. \& Wagner, M. (2006). Integrative management of sustainability performance, measurement and reporting. International Journal of Accounting, Auditing and Performance Evaluation, 3( I), I-19. doi: I0.1504/ IJAAPE.2006.010098

Spence, M. (1973). Job market signaling. Quarterly Journal of Economics, 87(3), 355-374. doi: I0.2307// 882010

Spencer, J. \& Gomez, C. (20II). MNEs and corruption: The impact of national institutions and subsidiary strategy. Strategic Management Journal, 32(3), 280-300. doi: 10.1002/smj.874

Stanaland, A., Lwin, M. \& Murphy, P. (20I I). Consumer perceptions of the antecedents and consequences of corporate social responsibility. Journal of Business Ethics, 102 (1), 47-55. doi: I0. I 007/s I 055 I-0 I I-0904-z 
Suchman, M. C. (1995). Managing legitimacy: Strategic and institutional approaches. Academy of Management Review, 20(3), 571-610. doi: |0.5465/amr. | 995.950808033|

Surroca, J., Tribo, J. A. \& Waddock, S. (2010). Corporate responsibility and financial performance: The role of intangible resources. Strategic Management Journal, 3I (5), 463-490. doi: I0. I002/smj.820

Surroca, J., Tribo, J. A. \& Zahra, S. A. (20I3). Stakeholder pressure on MNEs and the transfer of socially responsible practices to subsidiaries. Academy of Management Journal, 56(2), 549-572. doi: I0.5465/amj.20I 0.0962

Toffel, M. W. \& Short, J. L. (2009). Coming clean and cleaning up: Is voluntary disclosure a signal of effective self-policing? Harvard Business School Working Paper No. 08-098, I-42. doi: 10.2 I39/ssrn. I I 379 I 5

Turban, D. B. \& Greening, D.W. (1997). Corporate social performance and organizational attractiveness to prospective employees. Academy of Management Journal, 40(3), 658-672. doi: 10.2307/257057

Ullmann, A. A. (1985). Data in search of a theory: A critical examination of the relationships among social performance, social disclosure, and economic performance of U.S. firms. Academy of Management Review, I0(3), 540-557. doi: 10.5465/amr.1985.4278989

Vaccaro, A. (2012). To pay or not to pay? Dynamic transparency and the fight against the Mafia's extortionists. Journal of Business Ethics, 106(I), 23-35. doi: |0. 1007/s |055 |-0 I | - 1050-3

Våland, T. \& Heide, M. (2005). Corporate social responsiveness: Exploring the dynamics of "Bad Episodes." European Management Journal, 23(5), 495-506. doi: 10.10 I6/j.emj.2005.09.005
Van der Laan 'Smith, J., Adhikari, A., Tondkar, R. H. \& Andrews, R. L. (20 I0). The impact of corporate social disclosure on investment behavior: A cross-national study. Journal of Accounting \& Public Policy, 29(2), I77-192. doi: 10.10 16/j.jaccpubpol.2009.10.009

Vaughan, A. (20 I 8). BP's deepwater horizon bill tops \$65bn. The Guardian. Online article, January 16. Retrieved from https://www.theguardian. com/business/2018/jan/ / 6/bps-deepwater-horizon-bill-tops-65bn

Waddock, S. A. \& Graves, S. B. (1997). The corporate social performancefinancial performance link. Strategic Management Journal, I8(4), 303-319. doi: I 0. I 002/(SICI) | 097-0266( I 99704) | 8:4\%3C303::AID-SMJ869\% 3E3.0.CO;2-G

Wang, H., Choi, J. \& Li, J. (2008). Too little or too much? Untangling the relationship between corporate philanthropy and firm financial performance. Organization Science, 19(1), 143-159. doi: 10.1287/orsc. | 070.027 |

Wang, H. \& Qian, C. (20I I). Corporate philanthropy and corporate financial performance:The roles of stakeholder response and political access. Academy of Management Journal, 54(6), ||59-| |8|. doi: 10.5465/ amj.2009.0548

Wassmer, U., Cueto, D. C. \& Switzer, L. N. (2014). The effect of corporate environmental initiatives on firm value: Evidence from fortune 500 firms.M@n@gement, 17(I), I-19.doi: 10.3917/mana.171.000 I

Zhang, J. \& Wang, R. (2009). The role of information revelation in elimination contests. Economic Journal, 1/9(536), 613-641. doi: 10.111//j. | 468-0297.2008.02234.x 